\title{
Is this pill safe? Substandard medicines, mistaken solutions
}

$\mathrm{I}$ n most developing countries you can buy prescription medicines from street vendors and in corner stores, with no need for a doctor's note and with only the untutored vendor's suggestions as to dosage and side effects.

You might well wonder about safety. In some countries nearly half the common medicines on sale, such as antimalarial drugs, do not meet World Health Organization (WHO) quality standards. ${ }^{1}$ Pills may contain the wrong type or concentration of active ingredient, they may have deteriorated during distribution, or they may simply be fakes.

In Canada, Health Canada licenses medicines and monitors the market to detect and remove any that are poor quality, falsified or unregistered. According to the WHO, some 30 per cent of developing countries are unable even to maintain a registry of medicines, with devastating consequences for patients and public health. ${ }^{2}$

Strengthening regulatory authorities in developing countries is the urgent and logical way forward, yet the WHO is headed down a very different path.

The WHO-affiliated International Medical Products Anti-Counterfeiting Taskforce (IMPACT), which receives drug industry sponsorship, has instead focused governments' attention on policing knock-offs - medicines intentionally misrepresented as the product of a brand-name manufacturer. The taskforce is pressuring developing countries to pursue intellectual property enforcement as the best remedy for substandard medicines.

Counterfeit knock-offs are certainly a menace to companies' profits and reputations, but most evidence suggests the vast majority of substandard and falsified medicines are unrelated to criminal trademark infringement. Targeting a subset of the problem is not likely to ensure patient safety.

IMPACT participants insist the Task Force is simply a public-health initiative, yet they promote aggressive police

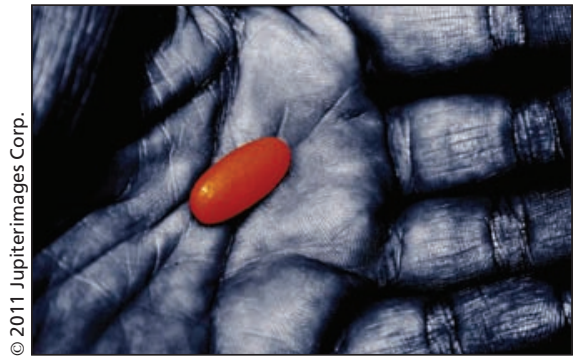

action on counterfeit medicines and, worryingly, employ an expansive definition that can encompass quality generic medicines, which are a lifeline for millions of patients in poor countries.

IMPACT representatives were among those lobbying for anticounterfeit laws in Kenya and Uganda. Under Kenya's law, the government would be obliged to enforce patents held in other countries on all medicines, even those not patented in Kenya, thus endangering access to affordable generic medicines to treat HIV/AIDS and other diseases. ${ }^{3}$ Not only would this do little for drug safety, it would divert the Kenyan government's scarce resources away from that urgent task.

Possible consequences were starkly revealed in the European Union, where the proposed enforcement rules have been adopted. Over the past two years at least 19 shipments of safe, quality generic medicines from India and Brazil, intended for patients in developing countries, were seized in transit in European ports for violation of EU patent regulations.

By reducing generic competition, such inappropriate policies can also drive up the price of medicines. And high prices are often why low-income households buy medicines that may be cheaper but are more likely to be ineffective or harmful.

Developing countries would be wise to remain focused on public-health measures to ensure that all medicines within their borders meet acceptable standards of quality. ${ }^{4}$

Some developing countries have successfully built drug regulatory authori- ties, like Brazil's ANVISA. Poorer countries, for whom a full-fledged regulatory authority is a long-term project, are trying innovative approaches, like a database of unregistered medicines traced to pharmaceutical outlets, and public information campaigns.

Other promising measures include expanded use of the WHO medicine prequalification program (which provides sound assessment of products) and cooperation with regulators from developed countries. In seven pilot countries, the Medicines Transparency Alliance has set up councils of health authorities, pharmaceutical companies and civil society groups to help identify substandard and falsified products on the market.

Such efforts bear no relationship to intellectual property enforcement. Substandard medicines are a serious threat to billions of people living in poverty. Canada ought to offer developing countries its considerable expertise in drug regulation, and use its seat on the WHO executive board to derail the mistaken notion that intellectual property enforcement can address this public health problem.

\section{Mark Fried \\ Policy Coordinator \\ Oxfam Canada \\ Ottawa, Ont.}

\section{References}

1. US Pharmacopeia/USAID. Survey of the quality of selected anti-malarial medicines circulating in Madagascar, Senegal, and Uganda. Geneva (Switzerland) World Helath Organization; 2009. Available: http://apps.who.int/medicinedocs/en/m /abstracts/Js17069e/ (accessed 2011 Feb. 16).

2. World Health Organization. Effective medicines regulation: ensuring safety, efficacy and quality. Geneva (Switzerland) The Organization; 2003. Available: http://apps.who.int/medicinedocs/en/d /Js4921e/ on (accessed 2011 Feb. 16).

3. Mbatiah S. Pharmaceutical companies pushing anti-counterfeiting law. IPS News. 2010 June 14. Available: http://ipsnews.net/news.asp?idnews= 51815 (accessed 2011 Mar. 7).

4. Oxfam International. Oxfam briefing paper 143: Eye on the Ball: Medicine regulation - not IP enforcement - can best deliver quality medicines. Oxford (UK): Oxfam; 2011. Available: www .oxfam.ca/sites/default/files/BP143-Eye-on-the-BallMedicine-Regulation-020211-en.pdf (accessed 2011 Mar. 7).

CMAJ 2011. DOI:10.1503/cmaj.110226

All editorial matter in CMAJ represents the opinions of the authors and not necessarily those of the Canadian Medical Association. 